\title{
The Impact of COVID-19 on Medical Education: An Indian Perspective
}

\section{ABSTRACT}

The Coronavirus Disease-19 (COVID-19) caused by Severe Acute Respiratory Syndrome Coronavirus 2 (SARS-CoV-2) has affected the human race across continents. Besides factories, food supply, transportation and travel industry; the education sector including medical education has also been adversely affected. It has been learned from experience over the last year that the coronavirus is here to stay for longer than expected. To mitigate the impact of the COVID-19 pandemic on medical education, new teaching methods and portals are being explored to bridge the gaps in learning across the nation over the last few months. Medical education is a fine blend of theory and practical training which is non negotiable. Online teaching as a sole alternative method for imparting education is being discovered and scrutinised. This article brings up a brief review about merits and barriers of e-learning in medical education in rapidly evolving scenarios from the Indian perspective.

Keywords: Alternative learning, Digital literacy, E-learning, Lockdown

\section{INTRODUCTION}

The COVID-19 is a zoonotic disease caused by a SARS-Cov-2 spread mainly through respiratory droplets. It was declared a pandemic by World Health Organisation (WHO) on March 11, 2020. Initially, because of the lack of specific treatment/vaccine, lockdowns were announced across the globe including India [1,2]. As estimated by United Nations Educational, Scientific, and Cultural Organisation (UNESCO), 107 countries had closed their educational institutions by March 2020 owing to COVID-19 affecting about half of the global population [3]. Campus teaching was suspended in medical schools too; elective postings, routine surgeries, and outpatient appointments were cancelled. Medical conferences were postponed/cancelled. Choi B et al., conducted an online survey on 440 final year medical students in 33 UK medical schools and found that $77.3 \%$ of respondents had their electives cancelled, $38.4 \%$ of respondents had their Objective Structured Clinical Examinations (OSCE) cancelled and $43 \%$ of assistantship placements were postponed [4]. The second wave of COVID-19 hit India in middle of March 2021 and by July 29, 2021, more than 31 million coronavirus positive cases were detected in India. Schools, colleges, and offices were closed, lockdowns (Corona-Curfew) were re-imposed in red zones. Though the second wave has receded in large parts of country (43509 new cases recorded on 29 July 2021), experts have warned about impending third wave around September-October 2021 which may involve children predominantly [5-7]. On 23 July 2021, WHO designated alert for 16 variants including B.1.427, B.1.429, B.1.466.2, B.1.621, B.1.629, C.36.3, P.2, P.3, etc., for further monitoring in various countries. It is feared that newer strains of coronavirus can cause severe illness and spread more rapidly than ever before [8]. Also, it is pertinent to understand that vaccination should not give a false sense of security and curbing transmission of the virus is still the key intervention to curtail mutations in virus and control pandemic [9]. Medical Universities across the world including Stanford, Harvard, and Yale have considered online programs as reasonable alternatives during the COVID-19 pandemic [10]. Medical education is a fine blend of theory and practical training which is non negotiable [11]. Online teaching as a sole alternative method for imparting education is being discovered and scrutinised.
This article brings up a brief review about merits and barriers of e-learning in medical education in rapidly evolving scenarios from the Indian perspective.

\section{E-learning: Experience so Far}

Broadly speaking, e-learning is any learning that is enabled electronically. It is also described as a system that uses internet technology to deliver information to students through computer interfaces. Brown AR and Voltz BD offered six elements of e-learning including activity, scenario, feedback, delivery, context, and influence [12]. Popovici A and Mironov C stressed that e-learning is equated with laptops, computers, I-pad, I-phones, 3D printers, etc., [13]. It is a reliable, reproducible, and ready to use model which can transcend geographical boundaries and time zones. Utility of blended or hybrid education which means the simultaneous use of classroom and online learning is being explored for years. Research by Riasati MJ et al., shared that integration of technology in teaching offered an enhanced overall collaborative teaching-learning experience [14]. Caroro RA et al., also pointed out through a survey that students of computer studies liked the online learning system as an educational tool but only as a supplementary option. They still preferred to attend regular classes [15]. Similar research on students at Universities in Indonesia and Jordan revealed parallel results $[16,17]$. However, as far as medical teaching is concerned, e-learning has never been the main mode of training doctors in India and elsewhere in the world.

\section{E-learning and Medical Education: Merits and Demerits} Medical education is a discipline that is distinct from other fields of education. It involves imparting practical skills which require real-time interaction and physical examination of patients. Paraclinical subjects (such as Biochemistry, Physiology, Anatomy, Microbiology, Pathology and Pharmacology) are covered in the first and second years of MBBS. In the third and final year, clinical subjects (like Ophthalmology, Ear, Nose and Throat, Community Medicine, Forensic Medicine, General Medicine, General Surgery, Obstetrics and Gynaecology, and Paediatrics) are taught to students where they interact with real patients and get hands-on training in outpatient and inpatient wards. Competency Based Medical Education (CBME) system was 
implemented at undergraduate level by Medical Council of India (MCl) in 2019 to address ethical, professional, and humanistic aspects of medical practice. It is a learner-centered and time-independent program which involves vertical and horizontal integration of subjects with temporal alignment [Table/Fig-1]. It also stresses early clinical exposure in the first year of training itself $[11,18,19]$. In wake of the COVID-19 pandemic, digital platforms are being increasingly utilised. Most theory lectures are given through online Power Point Presentations (PPP) and assignments are sought but practical training remain compromised.

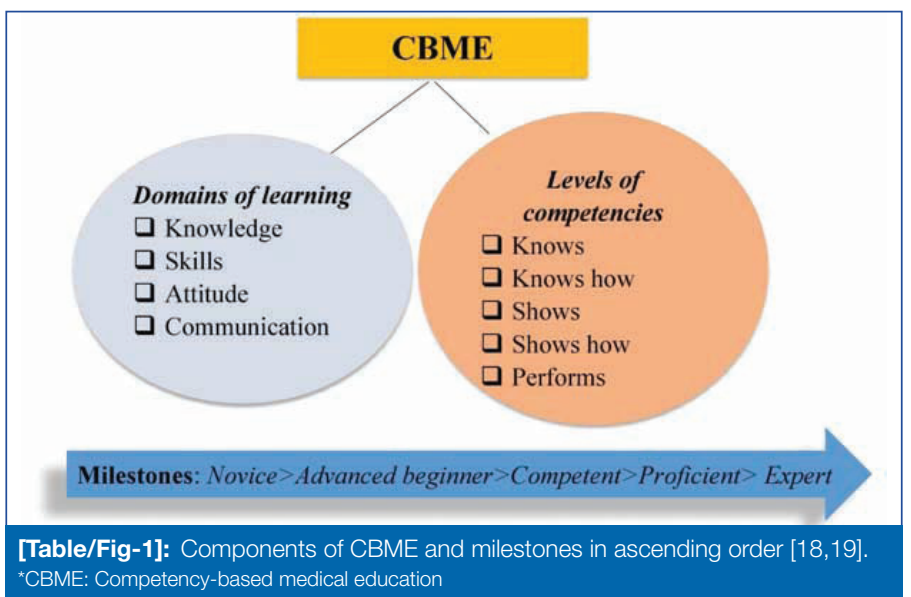

The evidence so far has suggested that e-learning has been around for years but further research is needed to explore and validate its role in health education. A recent survey on the second-year undergraduate (MBBS) students reflected that learning through online applications in addition to conventional teaching helped students perform better in subsequent assessments in the subject of pathology using WhatsApp [20]. A systematic review of 44 Randomised Controlled Trials (RCTs) reported that simulationbased medical training improved skill performance in 32 out of 44 (70\%) trials [21]. Utilisation of computer-assisted package, "Virtual Rheumatology" for acquiring musculoskeletal examination skills echoed positive outcomes in a cluster RCT in the United Kingdom [22]. Similarly Oncology trainees at Medical University in North India found Telemedicine beneficial for training [23].

However, online learning has some limitations/demerits pertaining to medical education. Real-time interaction with patients during classes, touching patients and examining them physically is a non negotiable part of medical training. Although e-learning can serve as a valuable tool to impart theoretical knowledge and some preliminary skills to undergraduates in the initial two years of training. But its role in postgraduate and super-specialty training particularly in clinical and surgical disciplines remains debatable. Moreover, neither the medical curriculum has been designed to impart education primarily on digital platforms nor are faculty and students trained to utilise such a forum. Kalita $J$ et al., stressed that both training and infrastructure is pertinent to imbibe a culture of computer-based learning [24]. Perceptions and attitudes of faculty and trainee doctors towards e-learning play a crucial role as well. Literature review revealed variable results in this subject matter. Some studies revealed that faculty and students had a positive outlook towards e-learning in higher education but the lack of tools and knowledge hampered teaching e-learning courses $[15,16,25,26]$. A recent study by Caroro RA and Jomuad MT, indicated e-learning was less effective in monitoring students and increased chances of copying assignments/tests [15]. Other issues included lack of technical expertise, internet access, and data affordability especially in resource constrained countries. The majority of students missed real-time interactions with the tutor. Besides, amongst faculty, some found it burdensome while others seem more concerned about the quality of teaching imparted through e-learning [25,27]. Some of the merits an demerits are listed in [Table/Fig-2] [25,28,29].

\begin{tabular}{|l|l|}
\hline Merits & \multicolumn{1}{|c|}{ Demerits } \\
\hline $\begin{array}{l}\text { Online material is reliable and } \\
\text { reproducible }\end{array}$ & Lack of ideal classroom environment \\
\hline $\begin{array}{l}\text { Accessibility across geographical } \\
\text { borders and time zones }\end{array}$ & $\begin{array}{l}\text { Poor digital literacy/lack of training } \\
\text { among students and faculty to utilise } \\
\text { online modes }\end{array}$ \\
\hline $\begin{array}{l}\text { Blended education can enhance } \\
\text { teaching/learning experience using } \\
\text { videos, 3D models. }\end{array}$ & Student-teacher bond is missing \\
\hline $\begin{array}{l}\text { Student can learn in his own time and } \\
\text { space }\end{array}$ & Practical training is sub-optimised \\
\hline $\begin{array}{l}\text { Faculty members/teachers can } \\
\text { collaborate and help each other }\end{array}$ & $\begin{array}{l}\text { Online classes require high data usage } \\
\text { which poor students may not afford }\end{array}$ \\
\hline $\begin{array}{l}\text { Students and clinicians from interior } \\
\text { locations can access information in their } \\
\text { handset }\end{array}$ & $\begin{array}{l}\text { Lack of high speed internet facilities in } \\
\text { far off areas }\end{array}$ \\
\hline $\begin{array}{l}\text { Better preparedness for future natural } \\
\text { disasters }\end{array}$ & $\begin{array}{l}\text { Increased onscreen time and sedentary } \\
\text { lifestyle can lead to health issues }\end{array}$ \\
\hline [Table/Fig-2]: Merits and demerits of e-learning [25,28,29].
\end{tabular}

\section{Strategies for Optimal Use of E-learning in Medical Education}

E-learning has the potential to mitigate gaps in medical learning during the ongoing COVID-19 pandemic. The situation demands extensive evaluation and stepwise modifications.

1) The issues related to imparting CBME to undergraduate students (MBBS) can be addressed in the following manner:

a) Cognitive domain: Pre-lecture assignments, audio-video clips, podcasts, animations, and web links for self-study.

b) Psychomotor skills: It can be upgraded to the "knows how" level via demonstration of procedures and interventions like intravenous cannula insertion, airway management, resuscitation, cardiac monitoring, etc., through online platforms and skill labs in a controlled environment.

c) Affective domain: Use of videos showing problem-based scenarios, counselling, communication skills, and role-plays [28-30].

2) The online resources can be utilised to impart education in such unprecedented times [Table/Fig-3]. The field of medical games can be also explored for teaching purposes [26,30-32].

3) Other important interventions include promoting crossinstitutional collaboration and strengthening tele-consultation health services [23,26,30].

4) Certain strategies can be adopted by faculty that create social presence like encouraging positive messages, timely response to queries raised by students, feedback from students, virtual workshops and problem-based learning [29,33].

5) Establishing mental health support team comprising of health professionals and counsellors for stress management and adopting healthy lifestyle practices including yoga, meditation, workouts [28].

\begin{tabular}{|l|l|}
\hline Web sharing applications & Zoom, Google Meet, Go-to-Meeting, Cisco-Webex \\
\hline $\begin{array}{l}\text { Free LMS software } \\
\text { systems for online teaching }\end{array}$ & $\begin{array}{l}\text { Talent LMS, Google Classroom, CANVAS, } \\
\text { Schology, Moodle Blackboard }\end{array}$ \\
\hline & $\begin{array}{l}\text { http://onlinelibrary.wiley.com } \\
\text { http://medbookshelf.info } \\
\text { http://www.freebookcentre.net } \\
\text { http://www.lecturio.com, } \\
\text { http://pubmed.gov } \\
\text { http://www.scholat.google.com } \\
\text { resources }\end{array}$ \\
$\begin{array}{l}\text { Social media applications } \\
\text { WhatsApp, Telegram, Facebook, Instagram }\end{array}$ \\
\hline [Table/Fig-3]: Online modes of learning/teaching [26,30-32]. \\
LMS: Learning management system
\end{tabular}

Future of E-leaning Post COVID-19- the New Normal

We are already in the transformative phase owing to the COVID-19 pandemic. As teachers and students can be asymptomatic carriers 
of the virus, interaction in small groups is preferable. Also, medical students are being engaged in the care of COVID-19 patients early in their careers. So, we need to devise ways to carry out medical teaching and patient care simultaneously and safely. Some of the measures have been proposed [Table/Fig-4], a lot still needs to be planned [28,29,34,35].

\begin{tabular}{|c|}
\hline A. Pertaining to theory classes \\
\hline $\begin{array}{l}\text { To start Institution based computer courses to impart digital training to faculty and } \\
\text { students. }\end{array}$ \\
\hline $\begin{array}{l}\text { To purchase electronic platforms offering video conferences/lectures by } \\
\text { institution. }\end{array}$ \\
\hline Separate Information Technology (IT) department in each medical institution. \\
\hline To familiarise students with concept and tools of e-learning. \\
\hline $\begin{array}{l}\text { To encourage students to actively participate during live classes and share their } \\
\text { online experience. }\end{array}$ \\
\hline To arrange practical training in small batches (alternate time intervals). \\
\hline To organise online stress management programs to dispel fear and panic. \\
\hline To strengthen tele-education. \\
\hline To conduct tests online or in small batches. \\
\hline To upgrade assessment system. \\
\hline B. Pertaining to practical training \\
\hline To promote practical training in skill labs. \\
\hline $\begin{array}{l}\text { To arrange real time interactions between non COVID patient-doctor in small } \\
\text { groups with proper safety measures. }\end{array}$ \\
\hline $\begin{array}{l}\text { To follow laboratory biosafety guidance related to COVID-19 as per WHO } \\
\text { guidelines } 2020 \text {. }\end{array}$ \\
\hline $\begin{array}{l}\text { To perform all procedure based on risk assessment basis and only by properly } \\
\text { trained and skilled personnel who observes strict adherence to protocols at all } \\
\text { times. }\end{array}$ \\
\hline To do initial processing of all samples in a validated biological safety cabinet. \\
\hline $\begin{array}{l}\text { To transport all materials within and between laboratories in a secondary container } \\
\text { after surface decontamination. }\end{array}$ \\
\hline $\begin{array}{l}\text { To use disinfectants like sodium hypochlorite }(0.1 \% \text { for surface spill and } 1 \% \text { for } \\
\text { blood spills), } 62-71 \% \text { ethanol, } 0.5 \% \text { hydrogen peroxide, phenolic compounds etc., } \\
\text { with proven activity against enveloped viruses. }\end{array}$ \\
\hline $\begin{array}{l}\text { To transport viral isolates and patient specimens from suspected or confirmed } \\
\text { cases labelled as Category A (infectious substance affecting humans) and } \\
\text { Category B (biological substance) respectively. }\end{array}$ \\
\hline $\begin{array}{l}\text { Air from laboratories especially respiratory labs should not be recirculated and } \\
\text { HEPA filtered if reconditioned and recirculated. }\end{array}$ \\
\hline $\begin{array}{l}\text { To wear personal protective equipment (including disposable gloves, wrap around } \\
\text { or front gowns, scrub suits with sleeves that fully cover forearms, head coverings, } \\
\text { shoe covers and eye protection like goggles or face shield). }\end{array}$ \\
\hline $\begin{array}{l}\text { To use respiratory protection (fit tested respirator like NIOSH-certified N95, EU } \\
\text { FFP2 or equivalent) as per risk assessment. }\end{array}$ \\
\hline C. Pertaining to patient assessment in clinics \\
\hline Stepwise screening of patients while strictly adhering to the protocols at all times. \\
\hline $\begin{array}{l}\text { Barrier enclosure devices for aerosol generating procedures like bronchoscopy and } \\
\text { intubation. }\end{array}$ \\
\hline $\begin{array}{l}\text { [Table/Fig-4]: Proposed measures to improve learning in a medical college/institution } \\
\text { during pandemic phase and thereafter [28,29,34,35]. } \\
\text { COVID: Coronavirus disease; HEPA: High efficiency particulate air (filter); NIOSH-certified N95: National } \\
\text { Institute for Occupational Safety and Health certification-N95 classification of air filtration; meaning that } \\
\text { it filters at least 95\% of airborne particles; FFP: Filtering face-piece }\end{array}$ \\
\hline
\end{tabular}

\section{CONCLUSION(S)}

COVID-19 has had a huge impact on human lives and the healthcare system, particularly the medical education sector. With recent outbursts, with supposedly new mutated coronavirus strains (like delta-plus in India), one needs to remain vigilant. With speculation of third wave of COVID-19 in coming times, persistence and adaptability amongst the medical fraternity is the need of the hour. E-learning is rapidly emerging as a popular emergency alternative portal of disseminating knowledge across geographical and time barriers. Whereas theoretical teaching can be delivered via digital platforms effectively, optimised practical training remains compromised. New strategies need to be explored to deliver an enriching online experience as a part of alternative teaching/learning during such unprecedented times.

\section{REFERENCES}

[1] Timeline of WHO's response to COVID-19 [Internet]. [cited 2021 Aug 1]. Available from: https://www.who.int/emergencies/diseases/novel-coronavirus-2019/interactivetimeline.

[2] Gupta R, Pal SK, Pandey G. A comprehensive analysis of COVID-19 outbreak situation in India. medRxiv. 2020 Apr 16;2020.04.08.20058347.

[3] Education: From disruption to recovery [Internet]. [cited 2021 Aug 1]. Available from: https://en.unesco.org/covid19/educationresponse.

[4] Choi B, Jegatheeswaran L, Minocha A, Alhilani M, Nakhoul M, Mutengesa E. The impact of the COVID-19 pandemic on final year medical students in the United Kingdom: A national survey. BMC Med Educ. 2020;20(1):01-11.

[5] Indian Academy of Pediatrics Covid Task Force. Indian Academy of Pediatrics (IAP) IAP viewpoint on the third wave of COVID-19 in INDIA. 2021.

[6] India reports 1.61 lakh coronavirus cases in 24 hours; recovery rate drops to 89.5\% - BusinessToday [Internet]. [cited 2021 Aug 1]. Available from: https:// www.businesstoday.in/latest/trends/story/india-reports-161-lakh-coronavirus cases-in-24-hours-recovery-rate-drops-to-89-percent-293363-2021-04-13.

[7] Coronavirus Outbreak in India- covid19india.org [Internet]. [cited 2021 Aug 1] Available from: https://www.covid19india.org/.

[8] Tracking SARS-CoV-2 variants [Internet]. [cited 2021 Aug 1]. Available from: https://www.who.int/en/activities/tracking-SARS-CoV-2-variants/.

[9] WHO/Europe / Media centre - Slow vaccine roll-out prolonging pandemic [Internet] [cited 2021 Aug 1]. Available from: https://www.euro.who.int/en/media-centre/ sections/press-releases/2021/slow-vaccine-roll-out-prolonging-pandemic.

[10] COVID-19- Moving Classes Online, Other Updates - Covid-19 Information [Internet] [cited 2021 Aug 1]. Available from: https://www.harvard.edu/coronavirus/covid19-moving-classes-online-other-updates/.

[11] Solanki A, Kashyap S. Medical education in India: Current challenges and the way forward. Med Teach. 2014;36(12):1027-31.

[12] Brown AR, Voltz BD. Elements of effective e-learning design. Int Rev Res Open Distance Learn. 2005;6(1):01-08.

[13] Popovici A, Mironov C. Students' perception on using e-learning technologies. Procedia-Soc Behav Sci. 2015;180:1514-19

[14] Riasati MJ, Allahyar N, Tan K. Technology in language education: Benefits and barriers. J Edu Prac. 2012;3(5);25-31.

[15] Caroro RA, Jomuad MT, Lumasag JM. Effectiveness of online learning system as a supplemental pedagogical tool. J Multidiscip Stud. 2013;2(1):2350-7020.

[16] Vitoria L, Mislinawati M, Nurmasyitah N. Students' perceptions on the implementation of e-learning: Helpful or unhelpful? J Phys Conf Ser. 2018;1088.

[17] Al-Adwan AS, Al-Adwan AS, Smedley J. Exploring students acceptance of e-learning using Technology Acceptance Model in Jordanian universities. Int J Edu Develop. 2013;9(2):04-18.

[18] Long DM. Competency-based residency training: The next advance in graduate medical education. Acad Med. 2000;75(12):1178-83.

[19] Basheer. Competency-based medical education in India: Are we ready? J Curr Res Sci Med. 2019;5(1):1.

[20] Sharma C. Impact of adding e-learning to the conventional pathology practical teaching. IP Arch Cytol Histopathol Res. 2019;4(1):01-10.

[21] Lynagh M, Burton R, Sanson-Fisher R. A systematic review of medical skills laboratory training: Where to from here? Med Educ. 2007;41(9):879-87.

[22] Vivekananda-Schmidt $P$, Lewis $M$, Hassell AB. Cluster randomised controlled trial of the impact of a computer-assisted learning package on the learning of musculoskeletal examination skills by undergraduate medical students. Arthritis Care Res (Hoboken). 2005;53(5):764-71

[23] Agrawal S, Maurya AK, Shrivastava K, Kumar S, Pant MC, Mishra SK. Training the trainees in radiation oncology with telemedicine as a tool in a developing country: A two-year audit. Int J Telemed Appl. 2011;2011:230670.

[24] Kalita J, Misra UK, Kumar G. Computer-based literature search in medical institutions in India. Ann Indian Acad Neurol. 2007;10(1):44-48.

[25] Frehywot S, Vovides Y, Talib Z, Mikhail N, Ross H, Wohltjen H, et al. e-learning in medical education in resource constrained low- and middle-income countries. Hum Resour Heal. 2013;11(1):01-15.

[26] Dhir SK, Verma D, Batta M, Mishra D. E-learning in medical education in India Indian Pediatr. 2017:54(10):871-77.

[27] Frazer C, Sullivan DH, Weatherspoon D, Hussey L. Faculty perceptions of online teaching effectiveness and indicators of quality. Nurs Res Pract. 2017;2017:9374189.

[28] Giliyaru S, Hegde G, Gajjala S, Vemuri O, Azzopardi C, Hurley P. COVID-19 pandemic and medical education. Indian J Med Sci. 2021;73(1):64-65.

[29] Hashilkar. E-Learning in health professionals' education. Indian J Phys Ther Res. $2021 ; 2(1): 66$

[30] Walsh K. The future of e-learning in healthcare professional education: Some possible directions. Commentary. Ann Ist Super Sanita. 2014;50(4):309-10.

[31] Fernández R, Gil I, Palacios D, Devece C. Technology platforms in distance learning: Functions, characteristics and selection criteria for use in higher education. WMSCI 2011- $15^{\text {th }}$ World Multi-Conference Syst Cybern Informatics, Proc. 2011;1:309-14.

[32] Free Online Teaching Guide PDF You Can Download | Symonds Training [Internet]. [cited 2021 Aug 1]. Available from: https://symondsresearch.com/ free-online-teaching-guide-pdf/.

[33] Plante K, Asselin ME. Best practices for creating social presence and caring behaviors online. Nurs Educ Perspect. 2014;35(4):219-23. 
[34] COVID-19 infection prevention and control guidance | WHO Western Pacific [Internet]. [cited 2021 Aug 1]. Available from: https://www.who.int/westernpacific/ emergencies/covid-19/technical-guidance/infection-prevention-control.
[35] Tran K, Cimon K, Severn M, Pessoa-Silva CL, Conly J. Aerosol generating procedures and risk of transmission of acute respiratory infections to healthcare workers: A systematic review. 2012;7(4):e35797.

PARTICULARS OF CONTRIBUTORS:

1. Assistant Professor, Department of Pulmonary Medicine, Shri Lal Bahadur Shastri Medical College and Hospital, Mandi, Himachal Pradesh, India.

2. Vice Chancellor, Atal Medical and Research University Campus, Shri Lal Bahadur Medical College and Hospital, Mandi, Himachal Pradesh, India.

3. Associate Professor, Department of Pulmonary Medicine, Government Medical College and Hospital, Chandigarh, Punjab, India.

\section{NAME, ADDRESS, E-MAIL ID OF THE CORRESPONDING AUTHOR:}

Dr. Surender Kashyap,

Vice Chancellor, Atal Medical and Research University Campus, Shri Lal Bahadur Medical College and Hospital, Mandi-175008, Himachal Pradesh, India.

E-mail: surenderkashyap@hotmail.com

\section{AUTHOR DECLARATION:}

- Financial or Other Competing Interests: None

- Was informed consent obtained from the subjects involved in the study? NA

- For any images presented appropriate consent has been obtained from the subjects. NA
PLAGIARISM CHECKING METHODS: [Jain Het al.]

- Plagiarism X-checker: May 08, 2021

- Manual Googling: Sep 07, 2021

- iThenticate Software: Sep 24, 2021 (9\%)
ETYMOLOGY: Author Origin

Date of Submission: May 07, 2021

Date of Peer Review: Jul 07, 2021

Date of Acceptance: Sep 08, 2021 Date of Publishing: Oct 01, 2021 